\title{
Halli Hulli Habi
}

af forfatter m.m. Mikael Witte

Søndag formiddag. Solen stikker lavt, selv det mindste kaster gigantiske skygger bag sig, men så trækker jeg min datter med ind i banegårdshallens mørke.

- Klakkelak, klakkelak, rapper gelænderet og hendes pind. Alt runger i en tunnel, tunnel. Vi klatrer op i interregionaltoget og jagter ledige pladser gennem Jylland.

For at afkorte ventetiden har vi diskuteret. Diskussioner ligger til hende. Fire år er hun.

- Bum, bummelum, bum, bummelum, synger sveller og tog. Hun tager straks ved lære og gentager.

- Bum, bummelum.

Toget er fyldt, vi burde have reserveret, jeg ved det, så vi havde fået et par gode pladser i børnekupéen, hvor hun kunne lege med ligesindede, Lego og lystige billeder på væggene. Omsider finder vi et par ledige pladser, det må være togets absolut eneste, og vi tager til takke med en ryger kupé. Jeg nikker undskyldende til de øvrige rejsende, ældre mennesker i Jylland, og vi fortsætter vores samtale.

Altså. Vi har talkt om klrokodillen i et badekar, hvor den røg en god cigar; om den gule ugle sad på en kugle da den spiste tre fugle; om man kan drysse kamel ud over risengrøden eller sætte sig overskrævs på kanel; hvad der er længst, armene eller tarmene, om vi skal sættes os i solen eller stolen. Eller begge dele? Måske.

Når man skal diskutere og solen hakker sine spidse syle ind, så kan man glemme sine medrejsende. Og dog. En ældre herre overrasker.

- Halli Hulli Habi Gummi Ladi Schaffalitzky Muckadell, præsenterer han.

- Hvor meget, undskylder jeg. Var Schaffalitzky Muckadell forfatter? 
Den ældre herre bøjer sig forover. Vi ind mod ham. Vi vil nødig forstyrre. Han præsenterer sig som ekshandelsrejsende, mest $\mathrm{i}$ korsetter, men det er længe siden, enhver slags og størrelse. Pæn avance. Flest laksefarvede, men også i sort. Fruerne bruger det ikke længere. Han skæmter vist. Født blev Erik Valdemar Bruun i Østervrå, i Vendsyssel, i 1912. Jeg nikker.

Som ung kneb det med terperiet i handelsskolen, hans terperi, ikke lærernes, forstås. En ældre kammerat lovede at lære ham alt om fordringer, debet og kredit. Ikke dårligt, nu han ville slå ind på handlesvejen. Det kneb fortsat, så kammeraten, Suurballe hed han, jeg nikker ad navnet, det kan man da huske, lærte ham - af pædagogiske grunde - en remse. Når den først sad, så skulle resten nok blive hængende. Det garanterede han, Suurballe.

Allerede før jeg når at svare, om vi vil høre den, rabler Erik Valdemar Bruun den af sig. Min datter jubler, vil høre den igen. Atter hamrer han remsen ud i den blå røg, uden at gispe efter vejret. Dette nonsens har han gemt på i næsten trekvart århundrede.

- Rent anarki, når man stikker faderen sutten! Hvad med en stjålne cigar?

- Jo, jeg fik en lille biks, man finder ud ad noget, en blandet biks, som man siger, Nordre Fasanvej.

- Og konen?

- Jo, jo, symaskinen griner stadig!

- Bum, bummelum, gentager min datter. Nu får jeg øje på de andre rejsende, fikserer dem. Også de har bøjet sig frem for at lytte med på Bruuns musikalske markedsgøgl, det rablende folkevid, den mundtlige overlevering der lever. Jeg ler.

Tegningerne lavede jeg bagefter.

Ælle vælle bum frikasse står på snuden af en ske man kan hverken høre eller se

Jeg kan huske da jeg lå i vuggen blev der sagt jeg var lidt skør i krukken

Jeg grinte bar"da min far sagde:

Du er ikke klar og så stjal jeg hans cigar

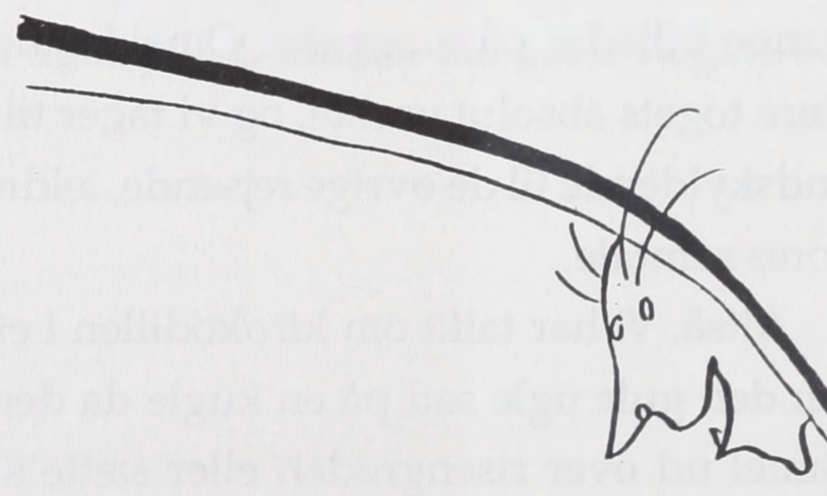


Med et grin jeg den i munden putted mens min far på sutten sutted

Op af vuggen skreg jeg:

Plads med dig jeg bytter

Og så vugged jeg min far

Jeg har aldrig gået i skole for jeg gik i byen men jeg ved da godt at Langelinies mole ender helt på Fyn
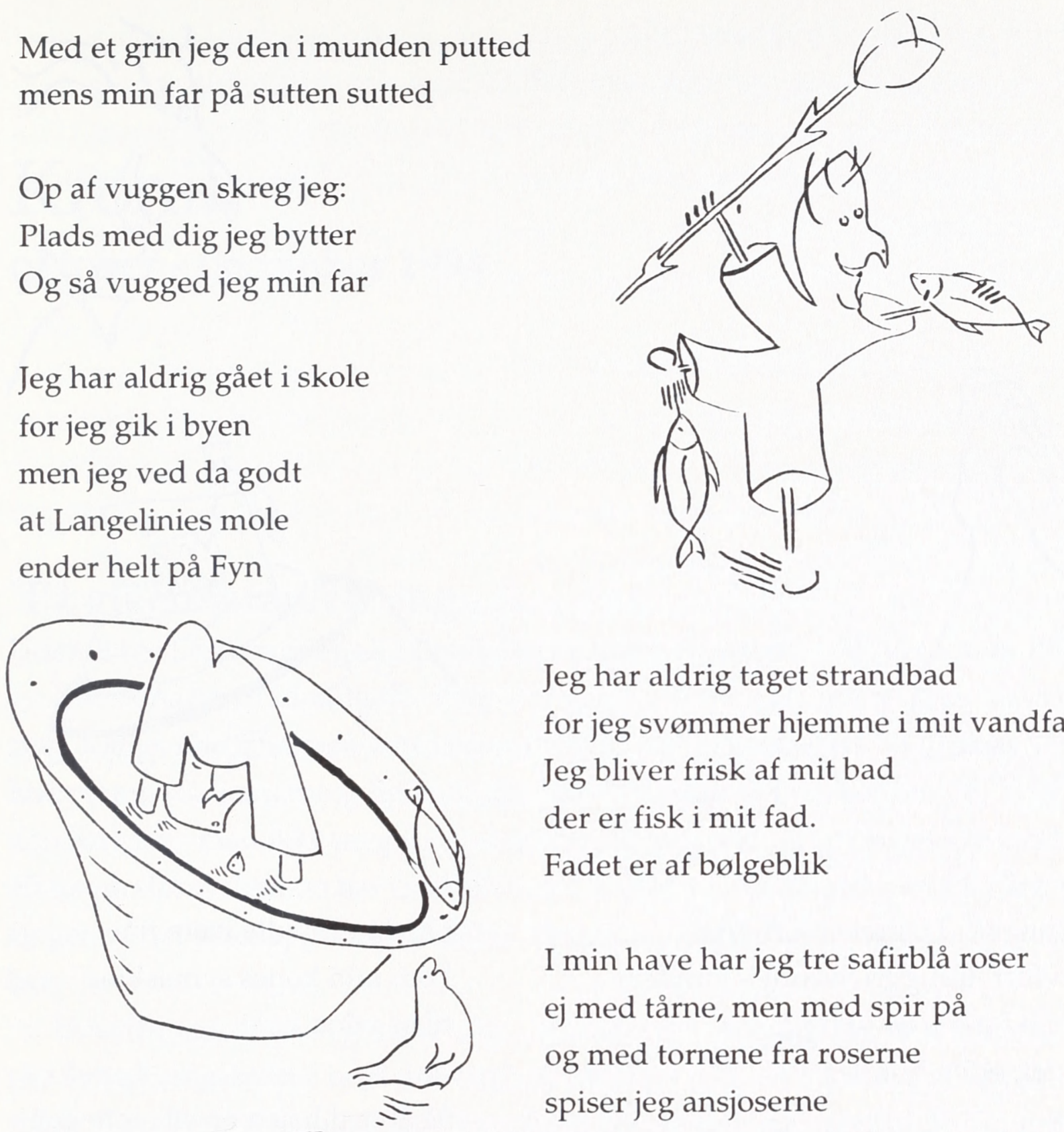

Jeg har aldrig taget strandbad for jeg svømmer hjemme i mit vandfad Jeg bliver frisk af mit bad der er fisk i mit fad. Fadet er af bølgeblik

I min have har jeg tre safirblå roser ej med tårne, men med spir på og med tornene fra roserne spiser jeg ansjoserne som jeg fanger på min krog

Der er ikke fler end tre tangenter på mit klaver

Jeg lader skægget stå og trække renter hos min barber

Varme boller spiser jeg med sne på om natten sover jeg med ble på

Fra Fællesvej på nummer ni sælger jeg et stort parti torskebukser uden knæ i

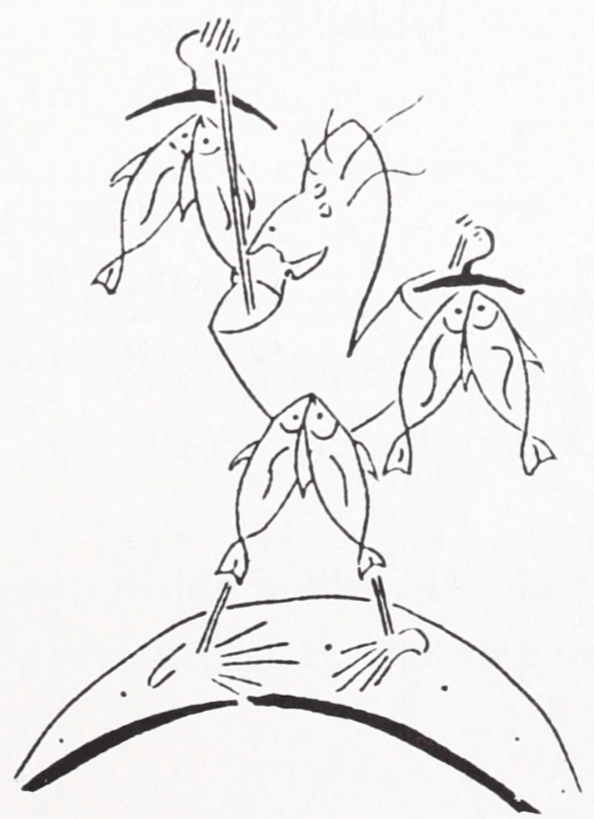




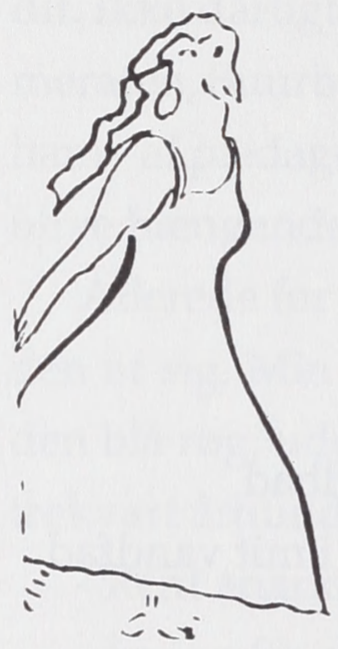

Jeg har altid været en original min forretning trives uden kunder og med mine træsko på går jeg uden bunder

120 kolibrier sad omkring på mine fine skilderier
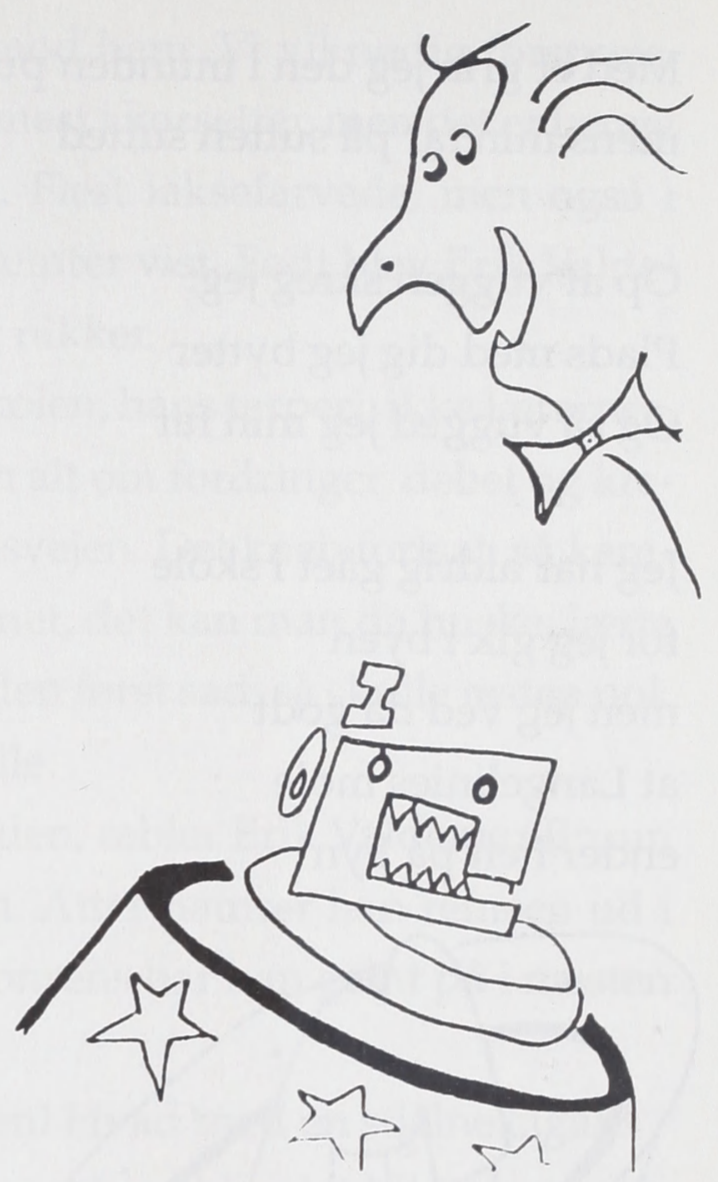

Og da vi skulle være fine kom min kones symaskine til at grine

Så åbned hajen op sit store gab og slugte hele vores klædeskab

HALLI HULLI HABI

GUMMI LADI

SCHAFFALITZKY MUCKADELL 